\title{
Vulnerable identities: Pious women columnists' narratives on Islamic feminism and feminist self-identification in contemporary Turkey
}

\author{
Didem Unal \\ Bilkent University, 06800 Ankara, Turkey
}

\section{A R T I C L E I N F O}

Available online 5 October 2015

\begin{abstract}
S Y N O P S I S
This paper presents the findings of a qualitative study on pious women columnists' negotiation of feminist self-identification in contemporary Turkey. Given the rise of the anti-feminist gender politics under the pro-Islamist AKP (Adalet ve Kalkınma Partisi) [Justice and Development Party] rule, it discusses how pious women columnists as crucial intellectual figures in the public sphere interpret feminism, Islamic feminism, and feminist self-identification. In this frame, the main aim of this study is to put forward the complexities of pious women columnists' positions in the public sphere and how this positionality affects their narratives about feminist self-identification in contemporary Turkey. Making use of the theoretical perspective provided by concepts such as "positionality" and "situatedness," this study concludes that negotiation of identity categories always takes place within the frame of reference, the contours of which is mapped out by one's position in the power configuration in society. Moreover, it brings into the open that the dialectical openings of Islamic feminism in pious women columnists' narratives can enhance the feminist coalitional politics in contemporary Turkey.
\end{abstract}

(c) 2015 Elsevier Ltd. All rights reserved.

\section{Introduction}

In the current neoliberal era, feminist self-identification has become a controversial terrain composed of myriad complexities. Scholars put forward that young women in Western Europe increasingly tend to disarticulate the "feminist" label, claiming that gender equality is already achieved and feminism is passé and unnecessary for contemporary social and political world. (Budgeon, 2001; Rich, 2005; Scharff, 2013) Moreover, it has been suggested that the neoliberal discourses of individualism and self-liberation, which in return result in repudiation of the feminist struggle for gender equality, are deeply embedded in political discourses and popular culture in the Western context today. (McRobbie, 2004, 2007) The rising anti-feminist discourse in the current era can also be clearly tracked down in the Turkish context with respect to the political agenda of the pro-Islamist AKP (Adalet ve Kalkınma Partisi) [The Justice and Development Party] government. Studies on AKP's gender politics reveal that the party's policies and political discourses have constantly reproduced traditional gender roles and confined women to familial roles (Çitak \& Tür, 2008; Coşar \& Yeğenoğlu, 2011). One can also allege that the patriarchal tones in AKP discourses have been further reinforced through attempts to disassociate feminism and gender equality and marginalize feminism as an extreme ideology. Keeping this antifeminist gender regime in mind, it is significant to ask how feminist self-identification is negotiated in Turkey in this particular era marked by a striking proliferation of anti-feminist political discourses.

The label "feminist" has always been very contentious in the Turkish context as everywhere else; yet one can argue that in a time period distinguished by the rise of anti-feminist discourses, public negotiations of feminist self-identification display multiple layers of complexity that are difficult to disentangle. This complex character of feminist self-identification in contemporary Turkey becomes even more intricate when vulnerable subject positions in the public sphere are taken into account. To comprehend how vulnerabilities in the public sphere influence 
the ways in which subjects make sense of identity categories in contemporary Turkey, this qualitative study examines pious women columnists' narratives on Islam, feminism, and Islamic feminism. In this way, it aims to gain a thorough insight into the narrative lines that pious women columnists resort to while explaining their relationship to feminism.

To this end, I will firstly discuss the anti-feminist tones underlying the gender politics of the AKP government and the discursive field in which anti-feminist discourses are reproduced through certain discursive opportunity structures. Having pointed out the high circulation of antifeminist discourses in public debates, I will delineate the peculiarities of pious women columnists' position in the contemporary social and political context in Turkey. Since every subject in the public sphere speaks from a particular location, experience, and context, it is vitally important to take into account research participants' positionality and situatedness. In this sense, the concepts of "positionality" and "situated reasoning," which connote a continuous engagement of the self into social and political reality (Alcoff, 2006: 94-95), provide a useful theoretical basis for the purposes of this study. These concepts enable one to see that judgments, perceptions, and demands are formed through the horizon of meanings available to subjects at a particular time and place. Making use of this theoretical perspective, this paper discusses pious women columnists' narratives on Islam, feminism, and feminist identity with a particular reference to the peculiarities of the interpretive horizons available to them in the current era. This context-based narrative analysis, in return, may provide us an understanding of how public vulnerabilities configure the contours of feminist self-identification in neoliberal times marked by a striking proliferation of anti-feminist discourses.

\section{The rise of the anti-feminist discursive regime under the AKP rule}

In the last decade, the main characteristics of Turkish politics has been subject to a radical change as a result of the rise of the pro-Islamist Adalet ve Kalkınma Partisi [Justice and Development Party] (AKP). For the first time in Turkish politics, a pro-Islamist political party could get the majority of the votes in four successive general elections, i.e., in 2002, 2007, 2011, and 2015, and has ruled the country with a new Islamist thinking marked by pragmatism rather than religious principles (Çavdar, 2006). As a part of this Islamic resurgence, conservatization in socio-cultural and political matters has come to the foreground. The party's approach to women's issues can be seen as a litmus test through which this conservatization crystallizes.

In the AKP's conservative politics, being a woman is first and foremost defined within the familial sphere through traditional gender codes (Çitak \& Tür, 2008; Coşar \& Yeğenoğlu, 2011; Unal \& Cindoğlu, 2013). To protect family unity, the AKP government aims to reinforce a strong commitment among citizens to the moral and political importance of the family ideal. It has attempted to implement policies to consolidate this ideal as a regulative principle in the social and moral imagination. Pronatalist policies constitute a main pillar of AKP's pro-family politics. Stressing the need for a young population in his speeches, PM Erdoğan frequently advises married couples to have at least three children:

"One or two children mean bankruptcy. Three children mean we are not improving but not receding either. At least three children are necessary in each family, because our population risks aging." (Hurriyet Daily News, 2013).

In addition to such pronatalist discourses defining the ideal number of children, the recent anti-abortion policy initiative could be identified as another reflection of this pronatalist vision. Upon Erdoğan's remarks in a public meeting in 2012, stating that abortion is murder (Radikal newspaper, 2012), a policy initiative appeared on the political agenda, which is designed to considerably reduce the time limit defined in law for the use of the right to abortion. Moreover, following this policy initiative, certain legal arrangements have been made, which restrict c-sections to medical emergencies. Through regulating women's reproductive capacities and their rights on their bodies, such discourses and policy initiatives see women's womb as a policy area that can be easily utilized for political purposes (Unal \& Cindoğlu, 2013). The result of this conservative emphasis on women's roles as mothers and wives is that familial roles assigned to women in the private sphere turn out to be the decisive element for their life choices.

Another major component of this patriarchal regime under the AKP rule is the articulation of distaste of feminist ideas. As in other prevalent streotypical accounts, feminism in AKP's discourses is closely associated with man-hating, extremism, and clash between men and women. In a meeting organized in 2008 by the party's women's branches, Dengir Mir Firat, AKP's former vice president, stated that feminist ideas foster the opposition between sexes and women from AKP cannot be slaves to feminism:

"Our view as AKP on women is very different from other parties and other segments of society. We do not support the clash between men and women as envisioned in the philosophical ideas in feminist thought. Women from AKP have never been slaves to feminism and never will be. Because we believe that men and women are inseperable and they complement each other." (Radikal newspaper, 2008)

On the other hand, in 2004, when hundreds of women gathered in front of the parliament in Ankara to protest the draft bill criminalizing adultery ${ }^{1}$ and shouted slogans "our bodies and sexuality belong to ourselves," PM Erdoğan expressed his anger by labeling the women activists as marginal:

"There were even those who marched to Ankara, carrying placards that do not suit the Turkish woman. I cannot applaud such behavior that does not suit our traditions and moral values... A marginal group cannot represent Turkish women." (Vatan newspaper, 2004)

The statements above clearly designate that feminism and the feminist movement in the AKP mindset is coded as antithetical to the image of the "ideal Turkish woman." In this anti-feminist discourse, feminism is further marginalized for 
being inherently prone to clash between sexes. As a result, it becomes the "other" of AKP's gender politics and is distanced from the party ideology altogether.

AKP's anti-feminist mentality also interprets "gender equality" as an alien concept, arguing that it does not comply with the party principles derived from Islamic values. The Dolmabahçe meeting, which was organized in 2008 to foster the dialog between the government and women's organizations yet resulted in sheer disappointment for feminists, is evidently reflective of the rejection of the concept of gender equality in the AKP mindset. During the course of this meeting, upon the question as to why he always frames the position of women within the confines of motherhood, PM Erdoğan took the initiative to elaborate on his views on gender equality and made the following statement:

"After all, I don't believe in the equality of men and women. Therefore, I prefer to say equality of opportunity. Women and men are different, they are complementary [mütemmim] to each other." (Vatan newspaper, 2010)

Erdoğan's remarks above replace the idea of gender equality with the religious concept of "fitrat" [disposition], which suggests that each and every being has its peculiar existence and is equipped with unique capabilities (Badran, 2009). Relying on the Islamic thought, Erdoğan intrinsically differentiates between male and female dispositions by seeing them as a part of the whole. Rather than talking about the equality of men and women, he promotes an understanding of equality of genders as human beings.

The discursive framework portrayed above clearly discloses the anti-feminist narrative lines in AKP politicians' speech acts. Instead of treating such speech acts in isolation, it is necessary to situate them within the existing discursive regime, identify their relation with statements having similar tones, and evaluate their effects on public debates. Drawing on the Foucauldian conception of discourse, Hall (2001: 73) states that discourse never consists of one statement, one text, or one action; the same discourse appears across a range of texts and speech acts. Accordingly, discursive statements that share similar motifs and narrative lines are products of the same discursive regime and generate certain discursive opportunity structures, enhancing political acceptability of certain ideas. According to Ferree, Gamson, Gerhards, and Rucht (2002), discourses that used to remain hidden or unnoticed may become highly visible in another discursive regime. Making use of the opportunity structures provided by the change in the governing rules of the discursive regime, certain speakers in the public sphere can articulate certain ideas more aloud or effectively. In this sense, one can allege that the rise of the anti-feminist discourse in government officials' speeches and the attempts to solidify it through legal arrangements expand the boundaries of the anti-feminist discourses in many other realms of the public sphere in contemporary Turkey. As a result, such discourses are extensively featured in the mass media forum, gain a widespread circulation in public debates, and become quite influential in shaping the trajectory of public debates on gender issues.

How do pious women columnists in contemporary Turkey position themselves vis-a-vis the rising anti-feminist discursive regime? As crucial intellectual actors, do they engage in a counter hegemonic attempt to challenge the patriarchal fixation of meaning in the realm of gender relations? In the light of these questions, this study investigates pious women columnists' positionality in the current hegemonic discursive regime in contemporary Turkey and the horizon of meanings that they rely on while constructing narratives on their relationship with feminism and feminist identity.

\section{Situating veiling and veiled women in the Turkish context}

Along the course of Turkish modernization, the deepest intellectual and emotional gaps between the modern West and Islam have come to the foreground most strikingly at the level of gender relations. The image of modern woman in the Republican mindset was a strategic means to prove Turkey's break with its past and its belonging to the Western civilization (Çınar, 2005). In line with this goal, the modern Kemalist woman was defined as a woman who actively participates in public life and is liberated from religious or cultural constraints of the intimate sphere. In this understanding, women had to make a radical choice about whether to be Western or be a Muslim (Göle, 1997: 86). Veiled women were perceived as the epitomes of the Orient, the traditional, the backward, and the "other" of the Kemalist modern women. Accordingly, being veiled and being a modern woman were thought to be at odds with each other in the Republican modernization project.

This bifurcation among women in terms of code of attire has gained new dimensions in the post- 1980 period. Islam that has been condemned to being the other of the urban, the rational, the modern, of what Kemalism praised, emerged in this decade in a quite different form that secularists did not know before. The headscarf was no more a matter of poor, rural, uneducated women but has acquired new connotations in the city (Genel \& Karaosmanoğlu, 2006). Young, urban, well-educated veiled women with professional identities have contributed to the redefinition of the meanings of veiling by displaying autonomous identities and asking for an all-inclusive public sphere. Presenting veiling as an act of free will and agency, they have discarded the essentializing Republican assumption that associates veiling with submission to patriarchy. As a result, they have revealed that old paradigms about veiling cannot explain the newly emerging dynamics of urban veiled women's identities.

The new generation of well-educated, urban veiled women have not only challenged the orthodox secularist Republican front but also contested the patriarchal dynamics of the rising Islamist politics. Especially those who have zealously worked for the mobilization of voters but were eventually excluded from the Islamist party cadres have posed serious criticisms against the symbolization of veiled women's identities and trivialization of their demands in Islamist politics in the 1990s and 2000s. ${ }^{2}$

The unrest among veiled women about the headscarf bans and the utilization of their identities has particularly risen in the final years of the AKP government. For a very long time, the AKP delayed political action to improve veiled women's rights in order to rebuff the opposition through a moderate stance and achieve other political goals with high priority such as winning elections. The party could attempt to lift the headscarf bans only in the aftermath of 2007 elections. In 2008, the AKP passed important constitutional amendments, making 
it possible for veiled women university students to enter universities with headscarf. In 2013, through a democratization package announced on September 30, it lifted the ban on wearing headscarves in public offices. Accordingly, public servants except prosecutors, judges, and military personnel acquired the right to wear headscarf in public offices. However, these recent improvements in the status of veiling could not eradicate mistrust and disappointment in veiled women's state of mind arising from AKP's long-lasting reluctance to lift the bans.

AKP's reluctance to lift the headscarf bans in public institutions has been severely criticized by pious women columnists. Hidayet Şefkatli Tuksal (2011) argued that for the last decade the AKP has ignored veiled women's efforts contributing to the party's electoral success and even prohibited the political attempts to grant veiled women the right to be elected. For Tuksal, this clearly shows that AKP's approach to veiled women is no different from the orthodox Republican understanding. In an interview that she gave to the press, Tuksal maintains that the AKP administration is aware of the fact that they are the only alternative for veiled women and can get their votes in any case:

"Unless the issue of headscarf is resolved, veiled women would not vote for another party. But the resolution of this problem would lead to the dispersion of the votes. As a result, the AKP may cease to be the only option." (Taraf newspaper, 2012)

PM Erdoğan's disdainful approach to the campaign "No Veiled Deputy No Vote" ${ }^{3}$ initiated in 2011 by veiled women activists and his interpretation of the campaign as an undemocratic, improper bargain further exacerbated pious women columnists' critique. As a response to PM Erdoğan, Nihal Bengisu Karaca (2011), a columnist in daily Habertürk, stated that veiled women's demands to be elected as MPs is a cry for a fundamental human right, not a bargain.

As pious women columnists' criticisms reveal, if one great obstacle to veiled women's position in society is the prevailing orthodox Republican discourses and the constraining legal framework, the other one is the discursive utilization of their identities in Islamist politics. Accordingly, the commonsensical assumption that veiled women's status in society has been irreversibly improved under the pro-Islamist AKP government that has remained in power for over a decade seems to be untrue. The age-old confrontation between the Islamist and Republican camps continues to reproduce itself through the symbolization of veiled women's identities for political purposes both in orthodox Republican and pro-Islamist political discourses. The interviews conducted in this study clearly demonstrate that pious women still feel vulnerable in the public sphere in contemporary Turkey as the utilitarian discourses applying to their identities remain intact.

\section{Pious women columnists as crucial intellectual figures}

The political struggles fought at universities over the issue of headscarf in the 1980s was succeeded by the emergence of pious women as influential actors in the intellectual arena in the 1990s. Starting with this period, pious women began to publish a considerable number of books-novels, collections of story stories, research books, doctoral theses-and attained crucial roles in the media sector.

These pious intellectual women are modern, urban, highly educated women who write not only for the Islamist community but also for the general public. Their weekly columns have appeared in Islamist newspapers as well as in mass circulation secular newspapers. In addition to publishing books and writing articles for journals and newspapers, some of them engaged in political activities to increase the electoral success of Islamist parties. Others have contributed to the foundation of civil society organizations that aim to enhance veiled women's status in society. In sum, the 1990s and especially the 2000s, have witnessed the emergence of pious women as influential public figures in different realms such as literature, journalism, politics, and activism.

The Republican definition of "ideal woman," which established a binary opposition between veiling and the symbolic and cultural capital in the Bourdieuan sense, is clearly challenged in the very persona of pious intellectual women who have left their imprint on the intellectual field. One should underline that the main difficulty that pious women have to confront in the intellectual field is not specifically their religiosity but their being a religious woman. This means that the challenges of being a pious woman writer have a dual character. On the one hand, pious women intellectuals have to struggle against the orthodox Republican reflexes of the intellectual field. Even though most of them write in pro-Islamist newspapers or magazines, as public intellectual figures appealing to wider audiences, their competence is frequently questioned as there is no conception of "veiled woman intellectual" in the Republican psyche. On the other hand, they also have to struggle against the patriarchal mind-set in the Islamist community. Being a well-educated woman writer who writes for national newspapers in a gender-conscious tone is a great challenge to the patriarchal gender relations in orthodox Islamist communities that confine women to traditional gender roles at home.

Pious women writers' dual critique of the Republican and Islamist fronts characterizes their quest for autonomous identities and distinguishes them from earlier generation of pious women writers. Opposing ideological projects that utilize their identities for broader social and political goals, the new generation of pious women writers attempt to find out novel ways of reconciling Islam with a gender-conscious thinking. Çayır (2007) notes that beginning with the 1990s, the writings of pious women writers have begun to display a considerably individualistic tone when compared to the earlier examples. Unlike the novels written in the 1980s with the aim to defend Islam against Westernized, secular lifestyles, the new form of Islamic novels in the 1990s deals with protagonists' questionings of religiosity, urban life, marriage, and love. This stress on women protagonists' inner conflicts and questionings reveals that the new generation of pious women writers in the 1990s regard writing as an inherent part of their quest to find out new ways to express their authentic selves.

While regarding writing as an empowering act that enables one to contest the marginalized aspects of identities, pious women columnists under consideration in this study also state that rather than being a free choice, writing for them has always been the last resort where they can go after having been rejected many times elsewhere. The hardships of performing 
their professional identities as lawyers, chemists, or sociologists have rendered them obliged to write columns or novels. In this sense, it is noteworthy to remember that each narrative that they produce, including the interviews in this study, is a manifestation of their discontent with the social, political, and cultural context. As pioneer women in the public sphere who have struggled against the entrenched secular-Islamist divide and the discriminatory state policies since the 1980s, pious women columnists speak from a vulnerable position that prompts them to produce cautious narratives through different strategies and elusive, intricate narrative lines. Their narratives remind us that marginalization of veiling and violation of veiled women's rights is an ongoing phenomenon in contemporary Turkey since recent legal achievements regarding veiling do not necessarily lead to the elimination of discriminatory discourses from society altogether. Therefore, as we will see below, pious women columnists negotiate feminist identity from within a frame of reference that reflects the myriad axes of vulnerabilities underlying their peculiar position in the public sphere.

\section{About the research}

This study relies on in-depth semi-structured interviews conducted with four pious women columnists, Hidayet Şefkatli Tuksal, Nihal Bengisu Karaca, Sibel Eraslan and Yıldız Ramazanoğlu, between January 2013 and June 2013. The writers interviewed in this study are influential figures who prolifically contribute to public debates and shape the public opinion in the Turkish context.

Hidayet Şefkatli Tuksal, who earned her doctoral degree in 1998 with a dissertation titled Kadın Karşıtı Söylemin İslam Geleneğindeki İzdüşümü (The Trajectory of the Misogynist Discourse in the Islamic Tradition), has written columns for Star and Taraf newspapers respectively between 2009 and 2012 and 2012-2013. In addition, Tuksal has been quite active in Islamist women's movement and has taken up a leading role in the foundation of Başkent Kadın Platformu (Capital Women's Platform), a women's organization led by pious women. Nihal Bengisu Karaca began her journalistic career in 1994 in Aksiyon, a weekly journal, where she later became an editor for the arts page. She also worked for Kanal 7 as a copywriter and program director. She wrote columns for Zaman newspaper, the weekly journal Yeni Aktüel, and currently writes for the daily Habertürk. Sibel Eraslan has written in mainstream national newspapers with a pro-Islamist stance, such as Yeni Şafak, Vakit, and Star. In addition to her journalistic career, she has also published novels, collections of short stories, and research books. Finally, Yıldız Ramazanoğlu has published ten books, including novels, collections of short stories, and essays. She has also contributed to national newspapers and journals and has participated in international women's submits as representatives of human rights and women's organizations.

The interviews in this study focus on women writers' ideas about feminism, feminist identity, and Islamic feminism, thereby aiming to reveal how they narrate their relationship to feminism in the current era. Acknowledging that feminist identity is not a monolithic entity, this study takes into account the complexity of feminist identity claims, different shades of feminist positions (weak, strong, etc.), and different reasonings (strategic, ideological, practical, etc.) involved in the negotiation of feminist identity. Moreover, it avoids from providing a list of predictors for measuring feminist identity and defining what feminism is. The fixation of feminism's meanings and the ideological components of feminist identity through operationalizing a list of predictors would be contrary to the aims of this study. Rather than evaluating women columnists' negotiation of feminist identity according to a fixed set of predictors, the aim here is to grasp how women columnists themselves operationalize feminist identity and what kind of narrative lines they use while approaching to the issue of feminist self-identification. In this sense, this study aims to examine women columnists' narratives on feminist self-identification by adopting a critical approach to essentialist interpretations of identity labels that fail to account for dynamic and multi-layered subject positionalities.

\section{Pious women columnists' narratives on feminism, Islamic feminism, and feminist identity}

When it comes to certain issues, pious women columnists display a critical stance vis-a-vis the patriarchal tones characterizing AKP's gender politics and the rising anti-feminist discourses in contemporary Turkey. For example, regarding the recent debates about the anti-abortion policy initiative in 2012, they openly opposed the government's attempts to impose restrictions on the right to abortion. ${ }^{4}$ Moreover, as noted earlier, they have posed harsh criticisms against the AKP's inertia that prevented it for a very long time from taking policy steps to improve veiled women's rights and liberties. In addition, they severely criticize the misogynist discourses of leading male intellectuals in the Islamist community. The criticisms that they pose against Ali Bulaç, an Islamist writer who argues against women's employment on the grounds that it imperils the family unity, are emblematic of their alert, critical stance vis-a-vis the high circulation of patriarchal statements in the Islamist community. ${ }^{5}$ Yet, this promising possibility of alliance with the feminist subaltern public is hampered when pious women columnists define feminism in stereotypical terms in order to disarticulate close association with it. Their narratives in this regard vary considerably depending on the social and political context and the secular feminist movement's approach to veiling and Islam. This study has shown that if the threat perception against Islamic selves and veiled women's position in society rises, then pious women columnists may clearly put a distance between themselves and the secular feminist subaltern public.

In this frame, one can suggest that pious women columnists' critique of the secular feminist movement in Turkey has a significant influence over their approach to feminist selfidentification and their conception of the coexistence of Islam and feminism. The autonomous feminist movement, when first emerged in the post-1980 era, was organized by middle class, well-educated, secular women and failed to incorporate veiled women's demands into its discourse. The divide between secular and religious women has come to be challenged only in the 1990s with the emergence of cleavages and multiplicities in feminist demands. Islamist and Kurdish women as well as the lesbian-gay-bisexual-transsexual (LGBT) movements have led to the disintegration of the monolithic conceptions of gender relations in Turkey and helped bring about a dramatic change in the history of feminist movements (Diner \& Toktaş, 2010). 
The rise of differences on the stage of feminism, in return, has led secular feminism to self-reflexive questioning of their basic premises and pointed out the necessity of adopting a stance that accommodates pluralities.

During the interviews I have observed that pious women columnists construct a cautious yet at the same time optimistic narrative on the secular feminist movement in Turkey. The stress on dialog and mutual understanding is a recurrent theme in their narrative lines. While explaining her position on feminism and the feminist movement, Sibel Eraslan makes the following statement:

"Cooperation, love, friendship... I take these concepts quite seriously. It is important that we can convey information via women's experiences and acts. Despite all the disagreements between us, whenever we, women in the media and literature, come together, we have always learned something from each other... I have come across good feminist women who make me feel secure, encourage me and make me laugh. I was lucky, I guess... Thus, feminism means friendship and solidarity for me..."

In a similar vein, cooperation is a prominent theme in Yıldız Ramazanoğlu's narrative where she argues that women need to live together side by side by acknowledging the importance of dialog:

"We do not have the luxury to live in our ghettos and produce constant opposition against each other. Everyone has a lot to share with each other... If we care to listen to each other, we can figure out how our differences can crosscut each other. Otherwise we become ghettoized to particular communities... We should not suffocate one another like this, condemning differences to certain identity categories."

This particular stress on cooperation, solidarity, and dialog represents an intersection point where Islamic references meet secular feminist ideals, generating a new position in between. It could be read as an expression of hybridity, dynamism, and change, which prepares the ground for a constant learning process from others' experiences. In this sense, pious women columnists' narratives expose novel, dialogic ways in which essentialist identity categories and the orthodox arguments defining Islam and feminism in binary opposition can be deconstructed.

Opposing the argument that Islam is a misogynist religion and Islamic practices are inherently against women's rights, Ramazanoğlu gives examples from the history of Islam pointing out the dignity and respect that women enjoyed in the Islamic tradition:

"Ontologically Islam is not a religion that suppresses women; rather, the opposite is true. There was this past tradition in Islam that urged fathers to rise out of respect when their daughters enter into the room. Each time when Fatima entered the room, our prophet rised because of his affection and respect for her."

Having justified the compatibility of Islam and feminism, Ramazanoğlu states that reading feminism through Islamic lenses enhances her conception of feminism and vice versa. She maintains that feminism gains a new perspective through a reading that is informed by the Islamic conception of equity [hakkaniyet], which, for Ramazanoğlu, is a concept that is superior to the feminist ideal of equality. It is based on the compatibility of men and women and forms expectations or allocates tasks and responsibilities according to the ontological capacities of both genders. Ramazanoğlu also denotes that when read in the light of the feminist framework, Islamic verses acquire new meanings beyond the patriarchal interpretations and the Qur'an is reconciled with contemporary feminist ideals. Therefore, she stresses that it is not possible to grasp the Qur'an fully without acknowledging the usefulness of feminist scholarship first. In sum, while reconciling her Islamic faith and her feminist stance, Ramazanoğlu utilizes the conceptual tools of the Islamic framework at one point and those of the feminist thought at another, which makes her narrative quite flexible. Therefore, one can argue that her conception of Islamic feminism corresponds to a very peculiar standpoint that makes it impossible to locate it into a stable category. Since her interpretive framework constantly shifts between Islamic and feminist standpoints, neither Islam nor feminism constitutes the permanent linchpin of Ramazanoğlu's conception of Islamic feminism. Rather, it is the dialectical relationship between Islam and feminism that makes her conception of Islamic feminism unique.

Similar to Ramazanoğlu, Hidayet Şefkatli Tuksal states that she constantly revises and renegotiates the meanings of Islamic feminism by engaging in a critical reading of both Islam and feminism:

"In the past everyone had to believe what the local religious leader said... But in time we, as women theologians, formed our own interpretations of the Qur'an and escaped the tyranny of misogynist interpretations... I believe that feminism refreshes my mind; it provides me alternative perspectives... Yet, I have reservations about the feminist discourse of gender equality. Which women are granted equality on the basis of feminist principles? ...I think about feminist principles a lot. I cannot think of myself saying 'feminism endorses this, so I definitely have to accept it like this; I don't like this rigidity."'

Tuksal denotes that Islam and feminism can be read in the light of each other in such a way that in the end they come to embrace multiplicities and different subject positions. In this sense, Tuksal's narrative is marked by a pendulum movement oscillating between feminist and Islamist frameworks. At certain points, she puts the emphasis on the feminist rereading of Islam; at other points, she prioritizes the Islamic framework and elaborates on exclusionary aspects of feminism that marginalize pious selves.

This dynamism and hybridity, which characterizes the narratives above, shift towards a more stable position in Nihal Bengisu Karaca's interview. Even though Karaca acknowledges that Islam and feminism can transform each other, she clearly identifies the Islamic framework as the keystone in the idea of Islamic feminism:

"What is important here is to disclose the ties that Islamic feminism has with the secular form of feminism in the 
West... If it is going to be called Islamic feminism, then the Islamic framework should be maintained as its reference point... If secular feminism constitutes the center of gravity in our conceptions of Islamic feminism, then you cannot call it Islamic..."

In this frame, one can conclude that pious women columnists acknowledge the coexistence of Islam and feminism and the transformative effects of the relationship in between, though in differing degrees. While some of the writers put a stronger stress on dialog and endorse hybrid standpoints where Islam and feminism engage in a dialectical relationship, constantly transforming each other, others adopt a stable position that prioritize Islam as the main reference point.

On the other hand, in all narratives, the call for dialog is accompanied by a cautious narrative line that reminds us of the still intact character of vulnerabilities underlying veiled women's positionality in contemporary Turkey. Pious women columnists particularly underscore that marginalizing discourses and violations of veiled women's rights and liberties are still in force in contemporary Turkey. In this regard, Tuksal's remarks are quite telling:

"A flea that is kept in a bottle can jump only as much as the bottle's height. It can jump only this much even after it is released... Our feelings of confinement are still intact under the AKP rule... It was only in the third period of the AKP rule that veiled women have begun to enter universities with their headscarves and participated into the workforce... Yet still, there is no legal guarantee to protect their veiled identities. Everybody knows that if another party replaces the AKP rule, all the achievements so far may vanish... Thus, we haven't started to dream yet..."

Tuksal's quotation above puts forward that pious women columnists negotiate identity categories in a context which, they think, still subjects them to a myriad axes of vulnerabilities. Contesting identity labels that deny multiple facets of identities and fix subject positions into hierarchically defined categories, pious women columnists are quite suspicious of identity labels such as "veiled woman" or "Islamist woman writer." They think that such labels are used in the public discourse with the aim to confine pious women's identities to an inferior essence.

This critical approach to identity categories encapsulates a deconstructive possibility to dismantle essentialist conceptions. On the other hand, at certain points, it falls short in providing a new ground where identities can be reconfigured as dynamic entities that allow subjects useful vantage points to make sense of their position in the social world (Alcoff, 2006). The tendency to code identity labels as inherently repressive constitutes a major obstacle imperiling the redefinitions of identities as enabling, multiple, and open to revision.

Vulnerabilities embedded in pious women columnists' positionality prevent them from clearly differentiating between essentialist impositions from outside and deconstructive possibilities to redefine identities as multiple and dynamic. As Alcoff (2006: 9) clearly points out, identities acquire their meaning as a result of complex processes of interpreting and working through a particular social location. They are never simply there before interpretation; their negotiation depends on the subject's experiences deeply grounded in her social location (Lloyd, 2005). Thus, rather than thinking of identity negotiations as processes that take place in isolation, one should acknowledge the peculiarities pertaining to the positionality of the subject in question and how this peculiar situatedness in return generates a frame of reference for the negotiation of identities. In this sense, the ways in which pious women columnists position themselves vis-a-vis the antifeminist discourses in contemporary Turkey, the secular feminist movement, and the idea of Islamic feminism can only be grasped by closely examining the interpretive site where they engage in meaning making processes. The discursive gender regime and pious women columnists' self-positioning in contemporary Turkey, which I have tried to portray so far, give us significant clues to make sense of their approach to feminism.

Pious women columnists' approach to feminist selfidentification further provides us a useful ground to comprehend the peculiarities of their positionality. For example, Eraslan's narrative in this regard is highly indicative of the tactical strategies that pious women columnists resort to while talking about their relationship with feminist identity:

"I do not openly say that I am a feminist. But they always call me Islamic feminist. If I have to say something, I use the term 'women's consciousness'... I prefer this shelter against all those traditional views criticizing feminism... Together with some friends, we use this phrase to explain our sensitivity without using the word 'feminist'. It protects me..."

The statement above clearly demonstrates the strategical gist in the disarticulation of feminist identity. Such strategical tactics can be interpreted as discursive tools utilized to avoid social ostracism associated with feminist self-identification both in secular and Islamist communities.

Another approach to feminist self-identification that stands out in pious women columnists' narratives is the reconfiguration of the meanings underlying feminist identity in line with the peculiarities of Islamic feminism. The line of reasoning in this approach can be evidently traced in Ramazanoğlu's narrative. When I ask her to define her relationship to feminism, Ramazanoğlu states that she is a "fragile feminist." For her, a fragile feminist is someone who criticizes feminism in terms of many aspects but at the same time takes the feminist acquisitions seriously and interprets the world through the feminist framework:

"I can define myself as a fragile feminist but this has nothing to do with being defined as feminist from outside... A fragile feminist position criticizes feminism, acknowledges its weaknesses but at the same time makes use of its accomplishments. It even includes a better understanding of Qur'an in the mirror of feminism..."

Ramazanoğlu stresses that she would accept to be called as "feminist" only if she herself defines what "feminist" means. Her stance vis-a-vis feminism is composed of a sui generis combination of a particular critique of feminist ideas and a reinterpretation of them through Islamic lenses. In this sense, the label "fragile feminist" used by Ramazanoğlu refers to a very peculiar position in which Islam and feminism get mixed 
in the same pot and gain further horizons. The term "fragile feminist" obviously entails an affirmation of feminist identity yet it also connotes a particular distance with feminism.

Similar to Ramazanoğlu, Tuksal uses a peculiar terminology when asked to define her relationship with feminist identity. She defines her stance as a "sui generis feminist" position and calls herself as a "thinking feminist" who constantly deliberates feminist ideas:

"I think about feminist ideas a lot... Therefore, I am probably a thinking feminist. Always questioning, always in search... Since the time when I first came across the feminist literature, I have always adopted this critical stance... I still try to negotiate feminist ideas and understand what good they do to me."

For Tuksal, the attempt to reconcile Islam and feminism is a relentless endeavor marked by shifts, instabilities, and questionings. This flexible approach to feminist identity does not imply a tactical move utilized to distance the self from feminism. On the contrary, Tuksal strongly affirms feminist self-identification by denoting the following:

"I have greatly benefited from the feminist literature and feminist research methods. In addition, I believe that the rights that women enjoy today have been achieved mainly thanks to feminist struggles. Therefore, if someone asks me whether I call myself feminist, I do not want to say 'No, I am not a feminist'. Because I find the feminist struggle significant...".

On the other hand, one should keep in mind that this firm commitment to feminist identity may also involve strategic concerns that modify the tone of the public articulation of feminist identity in accordance with the public context. Regarding this, Tuksal states that in big conferences or meetings where the compatibility of Islam and feminism is questioned, she feels the need to explain in detail what kind of feminism she has in mind. In this sense, Tuksal's narrative clearly reveals that articulation of a feminist position does not simply encapsulate the negotiation of feminist identity claims but also entails positioning vis-a-vis the public reception of the identity in question. From here, one can conclude that pious women's public articulation of feminist identity is heavily dependent on the public from which they speak. Their articulation of feminist identity position may get stronger or weaker, as they enter into different publics with different attitudes towards feminist self-identification and veiling. Tuksal's following statement is quite meaningful in this regard:

"Your feminist identity is welcomed in feminist circles while it is seen as a flaw in the Islamist community. The vice versa applies to your Islamist identity. You always have to face this dilemma."

Drawing on the statement above, one can argue that Tuksal's multiple belongings to Islamist and feminist communities and the discursive lines that accompany each identity position make it difficult for her to use stable identity labels.

In opposition to Tuksal's strong identification with feminism, Karaca strictly refuses to define her identity position through the label "feminist." She thinks that identity labels are restrictive in that they confine the self to a particular position while ignoring other aspects of life. Upon my asking where she locates herself within the Islamic feminist framework, Karaca states the following:

"I am not a person who confines herself to a single identity position. Neither do I define myself only as a mother, nor as a veiled woman and Muslim... Therefore, I would not define myself only as feminist or Islamic feminist either."

This stance shows us that for Karaca, self-identification with a particular identity position precludes belonging to other identity positions and thus cannot be reconciled with multiple belonging. In addition to her conception of identity labels as restrictive and uni-dimensional, another reason for Karaca to distance herself from Islamic feminist self-identification could be related to her critique of secular feminisms. In her mind-set, feminisms' secular character is so dominant that it leaves little room to re-interpret feminist premises through the Islamic framework. In this line of thought, feminist self-identification corresponds to a fixed set of premises that cannot be revised in line with one's needs and demands. It is quite paradoxical that despite her call for revision of essentialist, exclusionary aspects of secular feminism, Karaca fixes the meanings of feminism and feminist identity as inherently monolithic and exclusionary. This essentialist fixation discards the possibility of reconfiguring hybrid, dynamic and multiple identity positions in the realm of feminist politics.

As seen so far, pious women columnists' approaches to feminist self-identification constitute a wide, heterogenous array of identity positions, ranging from disavowal of identity categories to strategic tactics, from differentiation between being defined from outside and self-definition, to acknowledgment of contradictions embedded in multiple belonging. In this frame, different concerns and frames of reference influence pious women columnists' negotiation of feminist selfidentification in contemporary Turkey. While all writers in this study resort to various strategic tactics in their narratives to avoid stigmatization and negative labeling, some openly declare themselves as Islamic feminist and others rigidly deny any such labeling.

\section{Conclusion}

Every subject in the public sphere speaks from a particular location, experience, and context (Alcoff, 2006). The frame of reference in which the subject is embedded influences how she sees and interprets the social facts around her. In this sense, as seen in the discussions so far, pious women columnists' position in the public sphere maps out the contours of their negotiation of feminism, Islamic feminism, and feminist identity in contemporary Turkey. Their highly contingent and contextual narratives point out the vulnerable aspects of their positionalities and underscore that negotiation of identity categories always takes place within the frame of reference that is formed in line with one's position in the power configuration in society.

As pioneer women in the social and political life in Turkey, who have publicly contested discriminations against veiling and veiled women since the post-1980s, pious women columnists 
display quite intricate positionalities in the public sphere. They criticize both the secular front for its exclusionary discourses and the Islamist community for its patriarchal viewpoints. In this sense, their position as women intellectuals constantly shifts between different critical standpoints and is hard to pin down. This dynamic, hybrid critical position subjects them to different vulnerabilities in different contexts. While their veiling is seen as a threat in the secular front, their critical, pro-feminist stance is harshly criticized in the patriarchal Islamist community.

Pious women columnists' narratives disclose that marginalization of veiled women and violation of their rights is an ongoing phenomenon in contemporary Turkey. Although pious women columnists acknowledge the positive effects of the promising legal steps that have been taken recently to improve the status of veiling in society, they underline that these legal achievements do not guarantee the elimination of discriminatory discourses from society altogether. The cautious tones in their narratives clearly bring into the open the entrenched character of threat perceptions in pious selves.

Another prominent aspect in pious women columnists' narratives is the critique of essentialist conceptions of identity labels and the unique conception of Islamic feminism. Their narratives on Islam, feminism, and Islamic feminism expose novel ways in which the relationship between Islam and feminism can be redefined through a dialectical approach. The anti-essentialist critique here promises a significant potential to deconstruct the orthodox arguments defining Islam and feminism in binary opposition. Yet, on the other hand, it is striking to note that at certain points, pious women columnists' criticisms of secular feminism tend to reproduce essentialist, streotypical accounts of feminism in public discourses. Their coding of feminism as anti-family, anti-motherhood, or as inherently monolithic and exclusionary does not comply with their anti-essentialist critique of fixed identity categories. This contradictory stance can be seen as a rhetorical choice utilized by pious women columnists to stress the distance between the secular feminist position and the peculiarities of their positionality.

Despite the essentializing, streotypical reproduction of antifeminist public discourses in their narratives, one can argue that pious women columnists' critiques of both Republican and Islamist patriarchies and their attempts to reconcile Islam and feminism in a dialectical relationship render them potential allies of the secular feminist subaltern public. The pro-feminist tones in their narratives may imply a possibility of forming a coalition politics against the proliferation of anti-feminist discourses in contemporary Turkey. In this sense, pious women columnists' narratives constitute a critical discursive terrain where the visibility of profeminist discourses can be reinforced vis-a-vis the patriarchal gender regime and an active collaboration with secular feminist subaltern publics can be fostered. Yet, one should note that the Islamic feminist collaboration with secular feminist subaltern publics can be fully realized only if this collaboration is enhanced through an inclusive approach going beyond the essentializing limits of religious dictates. The dialectical expansion that materializes in a variety of strategic tactics and self-adopted labels in pious women columnists' narratives, such as "fragile feminist" or "thinking feminist," can greatly contribute to this ideal of inclusivity. It can bolster cooperation on pressing gender issues in contemporary
Turkey, such as women's sexuality, motherhood, and reproductive rights. In a nutshell, one can conclude that despite their limitations, pious women columnists' narratives on feminism and feminist identity have the potential of fostering a coalitional feminist politics against the rise of anti-feminist discourses in contemporary Turkey.

\section{Acknowledgements}

This paper partly draws on the author's Ph.D. research that is supported by TUBITAK (The Scientific and Technological Research Council of Turkey). The author would like to thank TUBITAK for the generous support.

\section{Endnotes}

${ }^{1}$ AKP's attempts to introduce a bill criminalizing adultery turned into a major crisis between the Turkish government and the European Union. As a result of the rising controversies, the proposed adultery law was withdrawn.

${ }^{2}$ In an interview that she gave to the feminist journal Pazartesi in 1995 , Sibel Eraslan, an activist and writer, openly criticizes the male hegemony in the Welfare Party. See Arat (2004).

${ }^{3}$ See http://basortuluadayyoksaoydayok.wordpress.com/basintoplantisi. Women activists as well as veiled women columnists who supported the campaign stated that political actions necessary for granting veiled women the right to be elected should not be delayed any more and all political parties, particularly the AKP, should take action against the violation of this fundamental human right.

${ }^{4}$ See Karaca (2012), Tuksal (2012), Ramazanoğlu (2012).

${ }^{5}$ See Tuksal (2010), Karaca (2010)

\section{References}

Alcoff, L. (2006). Visible identities: Race, gender and the self. NY: Oxford University Press.

Arat, Y. (2004). Rethinking the political: A feminist journal in Turkey, Pazartesi. Women's Studies International Forum, 27, 282-297.

Badran, M. (2009). Feminism in Islam: Secular and religious convergences. London: One World.

Budgeon, S. (2001). Emergent (?) feminist identities: Young women and the practice of micropolitics. European Journal of Women's Studies, 8, 7-28.

Çavdar, G. (2006). Islamist new thinking in Turkey: A model for political learning. Political Science Quarterly, 121, 477-497.

Çayır, K. (2007). Islamic literature in Contemporary Turkey: From epic to novel. New York: Palgrave-MacMillan.

Çınar, A. (2005). Modernity, Islam, secularism in Turkey: Bodies, places and time. Minneasota: University of Minnesota Press.

Çitak, Z., \& Tür, Ö. (2008). Women between tradition and change: The justice and development party experience in Turkey. Middle Eastern Studies, 44(3), 455-469.

Coşar, S., \& Yeğenoğlu, M. (2011). New grounds for patriarchy in Turkey? Gender policy in the age of AKP. South European Society and Politics, 16(4), 555-573.

Diner, Ç., \& Toktaş, Ş. (2010). Waves of feminism in Turkey: Kemalist, Islamist and Kurdish women's movements in an era of globalization. Journal of Balkan and Near Eastern Studies, 12(1), 41-57.

Ferree, M.M., Gamson, W.A., Gerhards, J., \& Rucht, D. (2002). Shaping abortion discourse: Democracy and the public sphere in Germany and the United States. New York: Cambridge University Press.

Genel, S., \& Karaosmanoğlu, K. (2006). A new Islamic individualism in Turkey: Headscarved women in the city. Turkish Studies, 7(3), 473-488.

Göle, N. (1997). The quest for the Islamic self within the context of modernity. In S. Bozdoğan, \& R. Kasaba (Eds.), Rethinking modernity and national identity (pp. 81-94). Seattle: University of Washington Press.

Hall, S. (2001). Foucault: Power, knowledge and discourse. In M. Wetherell, S. Taylor, \& S.J. Yates (Eds.), Discourse theory and practice: A reader (pp. 72-81). London: Sage.

Karaca, N.B. (2010). Ali bulaç'in problemi' (Ali Bulaç's problem) Habertürk, 4 August.

Karaca, N.B. (2011). Hak talebi ne zamandan beri pazarlk oldu?' (Since when are rights claims claims considered as bargain) Habertürk, 15 April.

Karaca, N.B. (2012). Kürtaj ve sezaryen' (Abortion and c-section) Habertürk. 30 May. 
Lloyd, M. (2005). Beyond identity politics: Feminism, power and politics. London: Sage.

McRobbie, A. (2004). Postfeminism and popular culture. Feminist Media Studies, 4(3), 255-264.

McRobbie, A. (2007). Top girls?: Young women and the postfeminist sexual contract. Cultural Studies, 21(4-5), 717-738.

Hurriyet Daily News (2013). 'Turkish PM reiterates his call for three children'. 3 January. http://www.hurriyetdailynews.com/turkish-pmerdogan-reiterates-his-call forthreechildren.aspx?pageID $=238 \&$ nid $=$ 38235.

Radikal newspaper (2008). 'AKP feminizmin kölesi olmayacak' (AKP will not be the slave of feminism) 5 May. http://www.radikal.com.tr/haber.php? haberno $=254895$

Radikal newspaper (2012). 'Başbakan: Her kürtaj bir uluderedir' (Every abortion is an Uludere) http://www.radikal.com.tr/Radikal.aspx?aType= RadikalEklerDeta3\&Articl D=108935\&CategoryID $=77$.

Ramazanoğlu, Yıldız (2012). 'Erkeklerin kürtajı' (Men's abortion) Zaman. 13 June http://www.zaman.com.tr/yorum_erkeklerin-kurtaji_1302783.html

Rich, E. (2005). Young women, feminist identities and neoliberalism. Women's Studies International Forum, 28, 495-508.
Scharff, C. (2013). Repudiating feminism: Young women in a neoliberal world. London: Ashgate.

Taraf newspaper (2012). 'AK Parti'de etkili üç cemaat var' (There are three influencial communities in the AK party) 29 October, http://www.taraf.com. tr/yazilar/nese duzel/hidayet sefkatli-tuksal-ak-parti-de-etkili-uc/23749.

Tuksal, H.Ş. (2010). Ali bulaç'ın yaman çelișkisi. (The difficult paradox of Ali Bulaç) Star newspaper, 4 August.

Tuksal, H.Ş. (2011). Keşke siz de zerdüșt olsaydınız. Winter: Amargi Feminist Quarterly.

Tuksal, H.Ş. (2012). Uluderede kürtaj yok, çocuk cinayetleri var (There are child murders in Uludere but no Abortion) Radikal newspaper. 6 June.

Unal, D., \& Cindoğlu, D. (2013). Reproductive citizenship in Turkey: Sbortion chronicles. Women's Studies International Forum, 38, 21-31.

Vatan newspaper (2004). Brüksel'de karşı çıktı, Ankara'da savundu [He opposed against it in Brussels but defended it in Ankara], 25 September. http://www. gazetevatan.com/bruksel-de-karsicikti-ankara-da-savundu-36744gundem

Vatan newspaper (2010). 'Kadınla erkek eşit olamaz' [Women and men cannot be equal], 20 July. http://haber.gazetevatan.com/kadinla-erkek-esit-olamaz/ 318006/9/siyaset 